\title{
Effect of irrigation treatments onmaize (Zea mays $L$.)Yield \& yield components during two growing seasons.
}

\author{
H. A. Sadalla1, J. B. Guznay2, T. F. Sadiq3, S. A. Kakarash4 \\ 1,2,3,4 (Field Crops, Agricultural College/ Salahaddin University, Iraq)
}

\begin{abstract}
Effect of five irrigation treatments on the yield and yield component of maize variety TALAR were studied at Gurdarash Research station. College of Agriculture, Erbil-Iraq during spring and fall season 2011.The result Showed significant differences among irrigation treatments for a must studied characters ear length, grain yield/plant, kernel/ear, 250 kernel weight and yield at both seasons. In spring season the total irrigation water used was about $\left(3503 \mathrm{~L} / 4 \mathrm{~m}^{2}\right)$, the value of must character were decreased. While in fall season the total irrigation water was about $\left(3177 \mathrm{~L} / 4 \mathrm{~m}^{2}\right)$ and the value of all characters were increased, the irrigation water was profitable for plant even at late maturity, which caused the higher irrigation efficiency in fall season than spring season according to crop productivity and less irrigation water used.

Keywords- irrigation, maize, yield component.
\end{abstract}

\section{Introduction}

Maize is one of important crops in Iraq, to increase the area cultivated with maize faced by water shortage. (Oweis and Hachum, 2004) had reviewed that the water is limited factor for agriculture not the land. To optimize yield per unit of water applied (irrigation efficiency). It would be wise to irrigate maize with less water, knowing when and how much water to apply and when to apply it. (Hamood and El-Sahoki, 2011) found that, the skip irrigation weekly gave grain yield $77 \%$ of that obtain from furrow planting irrigated weekly and save less than $50 \%$ of irrigation. The new method of field irrigation called Deficit Irrigation (DI)in which its aim to gave the higher crop productivity for each unit of irrigation water (kirda, 2002). D1 maximizes water productivity (wp) which is the main limiting factor (English, 1990). (Jejjo and AL-Zaidi, 2010) showed that the relative water efficiency under deficit irrigation increase with the increase in soil moisture percent depletion and irrigation deficit ratio. (Geerts and Rates, 2009) confirmed that deficit irrigation is successful in increasing water productivity for various crops without causing sever yield reduction. (Fahadet al., 2005) found the highest grain yield for control was $9.1 \mathrm{t} / \mathrm{ha}$, and lowest yield for deficit irrigation during flowering which was $7.6 \mathrm{t} / \mathrm{ha}$. (ALhenishet al., 2009) showed the delete the 5-6-7 irrigation during flowering reduced the grain yield about $25 \%$. Others found that water stress during grain filling caused the reduction in the yield about 42\% (Jurgens 1978). (Eck 1986) found that water stress for 2 weeks or 4 weeks during grain filling lead to reduce in the yield about $17 \%$ or $33 \%$ receptivity. All previous review concentrated on the irrigation deficit and its effect during plant growth specially during flowering period.

Therefore, this study was design to water save after silking period, because there were no study about irrigation efficiency and profitable for plant during this period and determined the last irrigation without effecting the grain yield.

\section{Materials and Methods}

This study was carried out at Grdarash Research station, College of Agriculture, Erbil - Iraq during spring and fall seasons of 2011. Soil characteristic presented in (Table 1), TALAR variety of maize (Zea mays L.) was used in this study. At both seasons a randomized complete block design with three replicates was applied. Each replicate consist of five plots $(2 * 2) \mathrm{m}$ and each plot consist of three rows. Seeds were sown at 25 $\mathrm{cm}$ apart with $75 \mathrm{~cm}$ between rows. The field was fertilized at rate of $400 \mathrm{~kg} / \mathrm{ha} \mathrm{N}: \mathrm{P}: \mathrm{K}(27: 27: 0)$ in two equal doses, half at sowing date and second after 40 days from sowing. Sowing dates were March 23 and July 13 for spring and fall seasons respectively.

Irrigation water was applied to treatment using surface irrigation system, the amount of water, applied by special counter, the water is applied after depletion reach $60-75 \%$ of available water according to (Hall et al., 1977, Kapur et al., 2004).

Gravimetric method used to measure and determine the time of irrigation as follow:

T1: the last irrigation was after 20 days from $50 \%$ silking.

T2: the last irrigation was after 27 days from $50 \%$ silking.

T3: the last irrigation was after 34 days from $50 \%$ silking.

T4: the last irrigation was after 41 days from $50 \%$ silking.

T5: the last irrigation was after 48 days from $50 \%$ silking. 
In both seasons,sample 5 plants from middle rows were taken for measurements of ear length, kernel ear, grain yield/plant, 250 kernel weight and yield. Statistical analysis was performed according to(Mohamad and Yonis, 2000).

\section{Result and Discussion}

Analysis of variance indicated significant differences among treatment at spring season for the character ear length, kernel/ear and 250 kernel weight (Table 2). Values of five studied characters are present in (Table 3), ear length and 250 kernel weight showed lowest value at T1. The character 250 kernel weight had highest value at T5 that because the number of kernel/ear decreased at T5, caused increase in size and weight of kernel. The longest ear found at T3 and maximum grain yield was at T2. In spite of the irrigation applied continuously until late maturity, but the kernel/ear, grain yield/ plant and yield decreased. The delay in silking until the beginning of Junecould cause a decrease in the number of seeds/ear and that could attributed to high temperature degree at that period (Figure 1) which kill pollen grain then caused unsuccessful fertilization in spring season, analysis of variance revealed significant differences for all studied characters except the character of 250 kernel weight at fall season were presented in table(4) the mean value of characters shown in (Table 5). The highest value for the characters ear length (20.47) cm, grain yield/plant (120.313) gm, kernel/ear (445.581) and yield (6.417) ton/ha. Were found at T5. This could be interpreted that flowering period occurred at September when the temperature decline, specially at night and early morning which important for fertilization, and attributed in seed set increase on ears, increasing No. of seeds/ear, grain yield/plant and yield.

Although the irrigation water used in spring season was high at T5 (3503) L/4 $\mathrm{m}^{2}$ comparing with fall season (3177) $\mathrm{L} / 4 \mathrm{~m}^{2}$ at $\mathrm{T} 5$ but most characters were decreased because of high temperature during flowering period and caused unsuccessful fertilization. Our conclusion that the fall season is better for yielding maize ability and the irrigation was profitable at T5 treatment, as well as the irrigation efficiency higher in fall season, which gave the higher crop productivity (6.417 ton/ha) for each unit of irrigation water (Kirda2002).

\section{References}

[1]. Oweis,T. and A. Hachum. (2007). Water harvesting and supplemental irrigation for improve water productivity of dry farming system in west Asia and North Africa. Natural Resource Management Program, International Center for Agricultural Research in the Dry Areas (ICARDA). Aleppo, Syria.

[2]. Hamood, J. A. and M .M. Elsahoki. (2011). Yield of maize under skip irrigation and planting depth. I. J. A. S. 42 (1): 1-12.

[3]. Kirda, C. (2002). Deficit irrigation scheduling based on plant growth stages showing water stress tolerance. In: Deficit irrigation practices. Water report No. 22. FAO, Rome, Italy.

[4]. English, M. (1990). Deficit irrigation. Analytical Frame work. J. I. D. E. 116 (3), 214-399.

[5]. Jajjo, N. M. and B. M. N. Alzaidi. (2010). Effect of Application uniformity or production under deficit sprinkler irrigation. ALRafidain Engineering Vol. 18. No.2.

[6]. Geerts, S. and D. Raes. (2009). The effect of plant density and water stress during vegetative phase on grain yield, yield components and water use efficiency of maize. Iranian Journal of crop Sci. 2 (3), 50 -62.

[7]. Fahad. A. A., S. A. El-hadethy and K. M. Malih. (2005). Maize (Zea mays L.) Water requirement in fall season cultivation under complete and deficit irrigation. Agric. Sci. vol 3 No 32: $315-323$.

[8]. EL- henish, T., M. R. EL- Ubaidy and K. EL- Smaiel. (2009). Effect of water stress on growth and productivity of some varieties and hybrids of maize in Der-Elzoor. $7^{\text {th }}$ Sci. Conf. of General Board of Scientific Agri. Res.

[9]. Jurgens, S.K. R. R. Johnson and J. S. Boger (1978). Dry mater production translocation in maize subjected drought during grain filling. Agron. J. 70: $678-682$.

[10]. ECK, H. V. (1986). Effects of water deficits on yield, yield components and water use efficiency of irrigated corn Agron. J. 78: 1035 -1040 .

[11]. Hall, D. G., Reeve M. J. and Thomasson A. J. (1977). Water retention, porosity and density of field soil. Printed in England by Adlard and Son limited Bartholomew press, Dorring.

[12]. Kapur, P. and Govil S. R. (2004). Experimental plant ecology. CBS publishers and Distributors New Delhi India.

[13]. Mohamad, F. and M.AL- yonis (2000). Agricultural experimentation design and analysis. Baghdad uni. Ministry of higher Education and Sci. Res. Part 1 and 2. Pp: 374 and 444 (in Arabic).

Table (1) soil properties:

\begin{tabular}{|l|l|l|l|l|l|l|}
\hline $\begin{array}{l}\text { PH } \\
1: 125 c^{0}\end{array}$ & $\begin{array}{l}\text { Ec } \\
1: 125 c^{0}\end{array}$ & N\% & O.M \% & K ppm & P ppm & Texture \\
\hline 7.35 & 0.36 & 0.137 & 1.23 & 118.08 & 5.58 & clay \\
\hline
\end{tabular}


Table (2): Mean of squaresofthestudiedcharacteristicsinspringseason.

\begin{tabular}{|c|c|c|c|c|c|c|}
\hline \multirow[b]{2}{*}{ S.O.V } & \multirow[b]{2}{*}{ df } & \multicolumn{5}{|c|}{ Mean of square } \\
\hline & & $\begin{array}{l}\text { Ear length } \\
\mathrm{cm}\end{array}$ & $\begin{array}{l}\text { Grain } \\
\text { yield/plant } \\
\text { g }\end{array}$ & Kernel/ear & $\begin{array}{l}\text { 250kernel } \\
\text { weight g }\end{array}$ & $\begin{array}{l}\text { Yield } \\
\text { t/h }\end{array}$ \\
\hline replicates & 2 & 2.067 & 152.259 & 2906.473 & 12.2 & 0.435 \\
\hline treatment & 4 & $4.067 *$ & 64.856 & 1382.554* & $133.567 *$ & 0.184 \\
\hline $\begin{array}{l}\text { Experimental } \\
\text { error }\end{array}$ & 8 & 0.567 & 39.699 & 543.079 & 28.617 & 0.113 \\
\hline Total & 14 & & & & & \\
\hline
\end{tabular}

Table (3): Mean ofthestudiedcharacteristicsinspringseason.

\begin{tabular}{|l|l|l|l|l|l|}
\hline $\begin{array}{l}\text { Characters } \\
\text { treatments }\end{array}$ & $\begin{array}{l}\text { Ear length } \\
\text { cm }\end{array}$ & $\begin{array}{l}\text { Grain } \\
\text { yield/plant g }\end{array}$ & Kernel/ear & $\begin{array}{l}\text { 250kernel } \\
\text { weight g }\end{array}$ & $\begin{array}{l}\text { Yield } \\
\text { t/h }\end{array}$ \\
\hline T1 & 13.33 & 30.688 & 146.72 & 51.67 & 1.637 \\
\hline T2 & 15 & 35.5 & 137.497 & 64.67 & 1.893 \\
\hline T3 & 16.33 & 26.625 & 107.369 & 62.67 & 1.42 \\
\hline T4 & 15.67 & 23.813 & 108.109 & 55.33 & 1.27 \\
\hline T5 & 14.66 & 25.875 & 97.07 & 67.67 & 1.38 \\
\hline LSD5\% & 1.418 & N.S & 43.88 & 10.072 & N.S \\
\hline
\end{tabular}

Table (4): Mean of squaresofthestudiedcharacteristicsinfallseason.

\begin{tabular}{|c|c|c|c|c|c|c|}
\hline \multirow[b]{2}{*}{ S.O.V } & \multirow[b]{2}{*}{ df } & \multicolumn{5}{|l|}{ Mean of square } \\
\hline & & $\begin{array}{ll}\text { Ear length } \\
\text { cm }\end{array}$ & $\begin{array}{l}\text { Grain } \\
\text { yield/plant g }\end{array}$ & Kernel/ear & $\begin{array}{l}\text { 250kernel } \\
\text { weight g }\end{array}$ & $\begin{array}{l}\text { Yield } \\
\text { t/h }\end{array}$ \\
\hline replicates & 2 & 0.605 & 34.389 & 817.371 & 16.467 & 0.98 \\
\hline treatment & 4 & 2.389* & 1183.221* & 21910.239* & 48.767 & 3.364* \\
\hline $\begin{array}{l}\text { Experimental } \\
\text { error }\end{array}$ & 8 & 1.003 & 127.761 & 2554.214 & 39.967 & 0.364 \\
\hline Total & 14 & & & & & \\
\hline
\end{tabular}

Table (5): Mean ofthestudiedcharacteristicsinfallseason.

\begin{tabular}{|l|l|l|l|l|l|}
\hline $\begin{array}{l}\text { Characters } \\
\text { treatments }\end{array}$ & $\begin{array}{l}\text { Ear length } \\
\mathrm{cm}\end{array}$ & $\begin{array}{l}\text { Grain } \\
\text { yield/plant g }\end{array}$ & Kernel/ear & $\begin{array}{l}\text { 250kernel } \\
\text { weight g }\end{array}$ & $\begin{array}{l}\text { Yield } \\
\text { t/h }\end{array}$ \\
\hline T1 & 18.9 & 69.688 & 258.338 & 67.67 & 3.717 \\
\hline T2 & 18.1 & 93.626 & 343.721 & 68 & 4.993 \\
\hline T3 & 19.4 & 83.626 & 291.2 & 72.67 & 4.46 \\
\hline T4 & 18.67 & 107.813 & 441.551 & 61.33 & 5.57 \\
\hline T5 & 20.47 & 120.313 & 445.581 & 67.67 & 6.417 \\
\hline LSD5\% & 1.886 & 21.282 & 95.157 & N.S & 1.136 \\
\hline
\end{tabular}

\begin{tabular}{||l|l|l|l|l|l|l|l|}
\hline \multirow{3}{*}{ Month } & \multicolumn{9}{|c|}{ Air temp. ${ }^{\circ} \mathrm{C}$} & \multicolumn{2}{l}{ Humidity \% } & Precipitation \\
\cline { 2 - 9 } & Avg. & Max. & Min. & Avg. & Max. & Min. & Depth mm. \\
\hline \hline Jan & 8.9 & 12.4 & 5.4 & 73.1 & 86.0 & 60.2 & 113.9 \\
\hline Feb & 10.0 & 13.8 & 6.3 & 72.6 & 87.9 & 57.3 & 42.8 \\
\hline Mar & 13.9 & 18.9 & 9.0 & 66.3 & 80.2 & 52.5 & 30.5 \\
\hline Aprl & 19.4 & 23.9 & 14.9 & 59.8 & 73.6 & 46 & 101.5 \\
\hline May & 25.0 & 30.2 & 19.7 & 46.4 & 61.2 & 31.6 & 12.7 \\
\hline Jun & 31.7 & 37.6 & 25.7 & 39.9 & 49.6 & 30.1 & 0.0 \\
\hline July & 25.5 & 41.9 & 21.1 & 27.0 & 36.1 & 17.9 & 0.0 \\
\hline Aug & 34.5 & 40.7 & 28.2 & 28.0 & 37.5 & 18.5 & 0.0 \\
\hline Sep & 29.6 & 35.6 & 23.6 & 35.1 & 45.1 & 25.0 & 0.0 \\
\hline Oct & 22.4 & 27.5 & 17.2 & 45.1 & 56.5 & 33.7 & 10.6 \\
\hline Nov & 12.5 & 17.0 & 8.1 & 55.0 & 69.9 & 40.1 & 7.4 \\
\hline Dec & 10.8 & 16.0 & 5.6 & 54.4 & 70.5 & 38.3 & 25.0 \\
\hline
\end{tabular}

